Prace Historyczno-Archiwalne t. XXXIII, Rzeszów 2021

ISSN: 1231-3335

\title{
Tadeusz Ochenduszko
}

ORCID 0000-0002-6691-5081

DOI:10.30657/pha.33.2021.06

(I Liceum Ogólnokształcące w Rzeszowie)

e-mail: taeuszochenduszko@wp.pl

\section{Egzaminy dojrzałości w galicyjskich szkołach realnych w latach 1872/73 - 1917/18}

\section{Streszczenie}

Egzaminy dojrzałości w galicyjskich szkołach realnych zostały wprowadzone w 1872 r., po wydłużeniu w nich nauki z sześciu do siedmiu lat.

Matura pisemna obejmowała: wypracowanie (zwane wtedy pracą klauzurową) w języku wykładowym, wypracowanie w języku państwowym, tj. niemieckim, przekład z języka niemieckiego na wykładowy lub odwrotnie, przekład z języka francuskiego na wykładowy, zadanie matematyczne oraz zadanie z geometrii wykreślnej. W Galicji w okresie autonomicznym językiem wykładowym we wszystkich szkołach realnych był polski. Na wypracowanie z języka polskiego i zadania z geometrii wykreślnej przeznaczone było po pięć godzin, na wypracowanie z języka niemieckiego i zadania z matematyki po cztery godziny, na przekład z języka niemieckiego na polski (lub odwrotnie) oraz na przekład z języka francuskiego na polski - po trzy.

Natomiast w części ustnej uczniowie zdawali: jeden język, geografię i historię (stanowiły wtedy jeden przedmiot), matematykę, historię naturalną (przyrodę), fizykę oraz chemię. Podczas ustnej części egzaminu w komisji zasiadali: przewodniczący, którym był zwykle krajowy inspektor szkół średnich lub delegat Rady Szkolnej Krajowej (RSK), dyrektor zakładu oraz wszyscy nauczyciele, którzy mieli zajęcia w klasie ostatniej, czyli siódmej. Matura miała charakter egzaminu publicznego, tak jak np. obrona pracy doktorskiej, zatem mogły się jej przysłuchiwać osoby postronne.

Na 18 szkół realnych, które funkcjonowały w wymienionym okresie, 15 spełniało warunki niezbędne do przeprowadzenia matury. Za przestrzeganie całej procedury dotyczącej egzaminu odpowiadali dyrektorzy zakładów, a w razie nieobsadzenia tych stanowisk - zastępcy dyrektorów, zwani też kierownikami. W latach 1872/73 - 1917/18 było ich 45.

Przewodniczącymi komisji podczas matury ustnej byli krajowi inspektorzy szkolni, ewentualnie delegaci RSK. Wybierano ich spośród członków RSK, osób przydzielonych do biur tej instytucji, pracowników wyższych uczelni, najczęściej tech- 
nicznych oraz dyrektorów innych szkół realnych. W okresie objętym niniejszym opracowaniem funkcję przewodniczących pełniło 33 urzędników. Nadzór nad największą liczbą matur (73) sprawował Jan Nepomucen Franke - przewodniczący działającej przy RSK Sekcji Szkół Zawodowych, Realnych i Przemysłowych.

W latach 1872/73 - 1913/14 egzamin dojrzałości zdało 7051 abiturientów. Stanowili oni 84,2\% tych, którzy podeszli do części ustnej. Najwięcej osób zdało maturę w I Szkole Realnej we Lwowie (1801) i I Szkole Realnej w Krakowie (1739). Najbardziej znanym absolwentem tej drugiej placówki był Józef Beck - minister spraw zagranicznych II Rzeczypospolitej w latach 1932-1939.

W specyficznym okresie I wojny światowej egzamin dojrzałości zdało około 750 osób, w tym prawie 46\% na mocy specjalnych przepisów, pozwalających uczniom udającym się na front składać w trybie przyspieszonym maturę wojenną. Wkrótce po odzyskaniu przez Polskę niepodległości szkoły realne zostały przekształcone w gimnazja. Te z nich, które po II wojnie światowej pozostały w granicach Polski, funkcjonują do dnia dzisiejszego.

\section{Słowa kluczowe:}

Szkoły realne w Galicji, matury w szkołach realnych, dyrektorzy szkół realnych, inspektorzy szkolni w Galicji, delegaci Rady Szkolnej Krajowej.

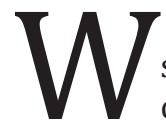

drugiej połowie XIX i na początku XX w. w Galicji funkcjonowały dwa typy szkół średnich. Były to cieszące się dużą popularnością i przyciągające więcej uczniów gimnazja oraz znacznie mniej doceniane przez opinię publiczną - szkoły realne. Gimnazja były instytucjami mocno zakorzenionymi w świadomości nie tylko mieszkańców Galicji, ale także obywateli całej monarchii habsburskiej, natomiast szkoły realne musiały przez dziesięciolecia zabiegać o prestiż w elitarnych kręgach społecznych ${ }^{1}$. Można zauważyć, że ukształtowana w XIX i na początku XX w. nieformalna hierarchia wywarła wpływ na zainteresowania badawcze historyków oświaty i kultury. Owocem ich prac jest sporo publikacji poświęconych gimnazjom oraz ich nauczycielom i wychowankom. Natomiast informacje, ich analiza oraz wnioski dotyczące szkół realnych pojawiają się często na drugim planie przy okazji badań poświęconych gimnazjom lub innym zagadnieniom dotyczącym kultury². Dlatego wskazane jest, aby kwestiom związanym z funkcjonowaniem szkół realnych poświęcić więcej uwagi zarówno w pracach przyczynkarskich, jak i w obszerniejszych publikacjach.

1 R. Dutkowa, Polityka szkolna w Galicji między autonomiq̨ a centralizmem (1861-1875), Kraków 1995, s. 156-157.

2 Przykładowe publikacje książkowe zob.: r. Dutkowa, Polityka szkolna w Galicji...; Studia z dziejów oświaty i kultury umysłowej w Polsce XVIII-XX w., red. r. Dutkowa, Wrocław-Warszawa-Kraków-Gdańsk 1977; J. Moklak, W walce o tożsamość Ukraińców. Zagadnienie języ$k a$ wykładowego w szkołach ludowych $i$ średnich $w$ pracach galicyjskiego Sejmu Krajowego 1866-1892, Kraków 2004; J. Moklak, Hałyczyna contra Galicja. Ukraińskie szkolnictwo średnie i wyższe w debatach Sejmu Krajowego galicyjskiego 1907-1914, Kraków 2013; M. Kulczykowski, Żydzi - studenci Uniwersytetu Jagiellońskiego w dobie autonomicznej (1867-1918), Kraków 1995; Z. Tabaka, Analiza zbiorowości studenckiej Uniwersytetu Jagiellońskiego w latach 1850-1918: studium statystyczne, Kraków1970. 
Warto wyjaśnić, że w pierwszej połowie XIX w. istniały nieliczne dwuklasowe bądź trzyklasowe szkoły realne, które starały się przygotować wychowanków do praktycznego funkcjonowania w różnych zawodach. Wypełniając swoje zadania, współpracowały ze szkołami ludowymi. Czasem połączone były z nimi wspólnym kierownictwem, a niekiedy korzystały z tego samego budynku. Nie miały one wtedy charakteru szkół średnich i dawały wykształcenie na poziomie trochę wyższym niż szkoły wydziałowe ${ }^{3}$. Przygotowywały do wykonywania konkretnego zawodu. W języku potocznym mówiono, że „dawały zawód”, „dawały fach”, czyli kształciły fachowców o średnim poziomie kwalifikacji.

Po Wiośnie Ludów, która omal nie doprowadziła do rozpadu monarchii habsburskiej, władze tego państwa przystąpiły do reformowania wielu dziedzin życia. Chcąc dać podstawy prawne pod solidne szkoły średnie, Ministerstwo Oświaty wydało Projekt zarysu organizacyjnego gimnazjów i szkół realnych, który 16 września 1849 r. uzyskał akceptację cesarza Franciszka Józefa I ${ }^{4}$. W oparciu o ten prowizoryczny i, według zapowiedzi, tymczasowy dokument ${ }^{5}$, uzupełniany z upływem lat poprawkami bądź nowymi paragrafami, przez ponad 70 lat funkcjonowały w Austrii, a później w Austro-Węgrzech szkoły średnie. Jak już wspomniano, było ich dwa typy: gimnazja, które dzieliły się na niższe - czteroklasowe i wyższe - ośmioklasowe ${ }^{6}$ oraz szkoły realne, również podzielone na niższe - trzyklasowe i wyższe - sześcioklasowe.

W oparciu o główne założenia Projektu zarysu organizacyjnego... Ministerstwo Oświaty opracowało Statut dla szkół realnych, który został zatwierdzony przez cesarza 2 marca 1851 r. Podobnie jak Zarys organizacyjny..., dzielił on szkoły realne na niższe i wyższe, pozostawiając tymczasowo jako relikt z pierwszej połowy stulecia trzeci rodzaj - niezupełnie niższe, które składały się z dwóch klas. Szkoły realne niezupełnie niższe przygotowywały do zawodów praktycznych, zwanych też fachowymi, realne niższe - do zawodów praktycznych i do kontynuowania nauki w realnych wyższych, a szkoły realne wyższe dawały podstawy do sprawowania funkcji nadzorczych i kontrolnych w zawodach praktycznych, ale nie uprawniały do podejmowania studiów. Z czasem szkoły realne niezupełnie niższe rozwinęły się do trzyklasowych albo zostały połączone ze szkołami handlowymi lub wydziałowymi.

Austriackie władze oświatowe, chcąc zapewnić absolwentom szkół średnich przygotowanie do studiów uniwersyteckich, wprowadziły w 1850 r. egzamin końcowy, zwany maturą lub egzaminem dojrzałości. Nie był on obowiązkowy, ale abiturienci, którzy go zdali, otrzymywali świadectwo dojrzałości. Dokument ten był niezbędny nie tylko do podjęcia studiów, ale także należało go przedstawiać przy podejmowaniu pierwszej pracy na etatach państwowych, w momencie rozpoczynania służby wojskowej, aby odbyć szkolenie dające uprawnienia do sprawowania funkcji

3 S. Możdżeń, Ustrój szkoły średniej w Galicji i próby jego modernizacji w latach 1848-1888, Wrocław 1974, s. 12.

4 Projekt zarysu organizacyjnego, [w:] Ustawy i rozporządzenia obowiq̨zujace w galicyjskich szkołach średnich, oprac. H. Kopia, Lwów 1900, s. 1.

5 Ten prowizoryczny dokument obowiązywać miał do momentu opracowania ostatecznej reformy szkół średnich. Po kilku latach, gdy widać było, że nie zanosi się, aby zastąpiony został dokumentem stałym, przestano nazywać go Projektem zarysu organizacyjnego szkót średnich, a zaczęto określać Zarysem organizacyjnym....

6 Przed reformą gimnazja miały sześć klas. Część z nich planowano zredukować do czteroklasowych, a część rozwinąć do ośmioklasowych. 
dowódczych, przy otwieraniu przewodu doktorskiego oraz rozpoczynaniu procedury habilitacyjnej i w innych ważnych w życiu momentach? ${ }^{7}$.

Matura była stopniowo wprowadzana w tych gimnazjach, w których pojawili się absolwenci klasy ósmej. Na przykład w Tarnowie i Przemyślu pierwszy egzamin dojrzałości odbył się w 1850 r., w Stanisławowie w 1852, a w Rzeszowie w 1860 r. ${ }^{8}$ Władze oświatowe przez dwa dziesięciolecia nie podjęły wysiłku, aby rozwinąć szkoły realne z sześcioklasowych do ośmioklasowych. Na skutek zaniechań zakłady te nie spełniały wszystkich warunków, pozwalających na zaliczenie ich do szkół średnich, a ich absolwenci nie nabywali praw do podejmowania studiów na uniwersytetach. Zalecenia Zarysu projektu organizacyjnego... z 1849 r. dotyczące matur nie zostały w nich wprowadzone. Między innymi z tych względów szkoły realne w oczach tzw. szerokiej publiczności cieszyły się mniejszym uznaniem niż gimnazja. Co jakiś czas podejmowano dyskusję, jakich zmian należy dokonać w ich programie i organizacji - czy większy nacisk położyć na wykształcenie ogólne, czy na praktyczne przygotowanie do zawodu i czy te dwa cele można skutecznie połączyć. Rozważano też przekształcenie większych zakładów w gimnazja realne, a wygaszenie mniejszych w ciągu sześciu lat. Polemika ta, wbrew zamierzeniom jej uczestników, nie zawsze poprawiała wizerunek szkół realnych.

Szansa na podniesienie ich rangi pojawiła się pod koniec lat sześćdziesiątych XIX w. w związku z reformą wyższych szkół technicznych, dla których szkoły realne miały stanowić podbudowę. Dyskusja nad przyszłością szkół realnych odbywała się w atmosferze klęski Austrii w wojnie z Prusami (1866 r.) oraz debaty nad reformą państwa i usprawnieniem wielu dziedzin życia społecznego. Czynnikiem sprzyjającym dialogowi było uzyskanie przez Galicję autonomii. Wymiana poglądów pomiędzy władzami państwowymi, autonomicznymi, autorytetami pracującymi na uczelniach oraz doświadczonymi pedagogami trwała do 1872 r. W jej trakcie, na mocy prowizorycznych decyzji, w niektórych krajach monarchii habsburskiej zaczęto wprowadzać zmiany programowe i organizacyjne, polegające m.in. na przedłużeniu nauki o jeden rok $^{9}$. Zostały one usankcjonowane rozporządzeniem Ministerstwa Wyznań i Oświaty z 24 lipca 1872 r., które zwiększyło liczbę klas w szkołach realnych niższych z trzech do czterech, wydłużając naukę w całym cyklu kształcenia z sześciu do siedmiu lat. Dzięki tej zmianie absolwent niższej szkoły realnej mógł nie tylko kontynuować naukę w wyższej szkole realnej, ale także, w przypadku zmiany zainteresowań, być przyjętym do gimnazjum wyższego (klasy V-VIII).

Inne rozporządzenie z 9 maja 1872 r. wprowadziło w szkołach realnych egzamin dojrzałości, który uprawniał absolwentów do wstępowania na zreformowane wyższe szkoły techniczne ${ }^{10}$. Pierwsze matury mogły odbyć się w tych placówkach,

7 T. Ochenduszko, Wojenne egzaminy dojrzałości, „Prace Historyczno-Archiwalne”, t. XXXII, Rzeszów 2020, s. 52.

8 Sprawozdanie Dyrekcji Gimnazjum w Przemyślu za rok szkolny 1894 [dalej: Spr. Dyr. Gim. ... za r. szk.], Przemyśl 1894 [dalej: miejsce i rok wydania sprawozdania pomijam], s. 118; Spr. Dyr. Gim. w Rzeszowie za r. szk. 1861, s. 49; T. Ochenduszko, Szkoły średnie w Stanisławowie w latach 1666-1918, „Prace Historyczno-Archiwalne”, t. XXVIII, Rzeszów 2016, s. 54.

9 Sprawozdanie C.K. Rady Szkolnej Krajowej o stanie szkół średnich galicyjskich w latach szkolnych 1875-1883, cz. II, Lwów 1885, s. 174.

10 Dziennik Ustaw i Rozporządzeń Krajowych dla Królestwa Galicji i Lodomerii wraz z Wielkim Księstwem Krakowskim [dalej: Dz. U. i Rozp. Kraj.], r. 1872, cz. XXXV, nr 66, s. 117. 
które zdołano rozwinąć do siedmioklasowych. We Lwowie nastąpiło to w roku szkolnym 1872/73, w Krakowie - 1873/74, w Jarosławiu - 1874/75, w Stryju - 1876/77, a w Stanisławowie - $1877 / 78^{11}$.

Organizując maturę w szkołach realnych, władze oświatowe bazowały na rozwiązaniach prawnych obowiązujących w gimnazjach. Warto zatem przypomnieć najważniejsze z nich. Po 1850 r. część pierwsza matury (pisemna) odbywała się przed wakacjami, a druga (ustna) w ciągu pierwszych czterech tygodni po rozpoczęciu nowego roku szkolnego. W 1854 r. ustna część matury została przeniesiona na koniec roku szkolnego, ewentualnie na początek wakacji.

Egzaminowi pisemnemu przewodniczył zwykle dyrektor szkoły, a w okresach przejściowych, w których nie było dyrektora - kierownik. Natomiast nad egzaminem ustnym nadzór sprawował krajowy inspektor szkół średnich lub delegat wyznaczony przez władze oświatowe (do 1868 r. przez Ministra Wyznań i Oświaty w Wiedniu, a później przez galicyjską Radę Szkolną Krajową we Lwowie). W wyjątkowych wypadkach na delegata władz oświatowych mógł być wyznaczony dyrektor, ewentualnie kierownik szkoły. Abiturienta, który nie spełnił wymagań stawianych na egzaminie, choćby tylko z jednego przedmiotu, komisja egzaminacyjna reprobowała na pół roku, a jeżeli dostrzegła większe braki - na rok. Po upływie wyznaczonego terminu musiał się poddać egzaminowi ze wszystkich przedmiotów ${ }^{12}$.

Egzamin powtórkowy młody mężczyzna zdawał w siedzibie inspektora, tj. we Lwowie. Później wyodrębniono na obszarze Galicji dwa okręgi szkolne. Siedziba wschodniego mieściła się w stolicy prowincji, a zachodniego - w Krakowie (podział Galicji na Zachodnią i Wschodnią istniał formalnie w latach 1854-1860, ale pragmatyzm urzędników spowodował, że w praktyce utrzymano go w wielu resortach). Przy powtórnym egzaminie komisja mogła teoretycznie zwolnić byłego ucznia z tych przedmiotów, z których podczas pierwszego podejścia wykazał się dużym zakresem wiedzy i wieloma umiejętnościami. Jeżeli za drugim razem nie sprostał wymaganiom, mógł zwrócić się do krajowego inspektora o specjalne pozwolenie na zdawanie matury po raz trzeci. Czwartego terminu przepisy nie przewidywały ${ }^{13}$.

Te ostre rygory w praktyce okazały się nieżyciowe. Zdarzało się, że młodzieniec składający egzamin, który dawał mu społeczny status inteligenta, posiadał poważne braki z jednego przedmiotu, a pozostałe zaliczał na poziomie dobrym. Członkowie komisji mieli wtedy dylemat, czy zawyżyć mu ocenę z dziedziny, z której się nie przygotował, czy też orzec o konieczności powtórzenia egzaminu za pół roku. Przepisy prawne rozwiązały ten problem w 1866 r., kiedy to wprowadzono poprawczy egzamin maturalny. Mógł on dotyczyć jednego lub kilku przedmiotów. Miał się odbywać nie wcześniej niż 6 tygodni od zakończenia matury ustnej przeprowadzanej w trybie normalnym. W praktyce, ze względu na organizację roku szkolnego, matury poprawkowe odbywały się pod koniec sierpnia w zakładzie, do którego wcześniej uczęszczał abiturient. Po kilku latach przeniesiono je na wrzesień.

Pomysłodawcy matury i autorzy Zarysu organizacyjnego... zakładali, że celem tego egzaminu nie będzie sprawdzanie szczegółowych wiadomości z poszczególnych lekcji, ale zbadanie ogólnej orientacji abiturienta, jego dojrzałości, umiejętności ogólnego my-

11 S. Możdżeń, Ustrój szkoły średniej..., s. 126.

12 Historia Gimnazjum Przemyskiego, [w:] Spr. Dyr. Gim. w Przemyślu za r. szk. 1894, s. 118.

13 Dz. U. i Rozp. Kraj., r. 1872, cz. XXXV, nr 66, s. 126-127. 
ślenia, udowadniania tez przy pomocy wybranych przez niego przykładów. Egzamin miał być luźnym kolokwium, a nie kontrolą szczegółowych informacji ze zdawanych przedmiotów. W praktyce jednak egzaminatorzy odchodzili od tych idealistycznych założeń, rozbudowywali materiał podlegający kontroli i wymagali wielu szczegółów. Dlatego co pewien czas władze szkolne przypominały, że zasadniczym celem matury jest sprawdzenie, czy abiturient jest przygotowany do uczestniczenia w zajęciach na wyższych uczelniach, ewentualnie, czy jako pracownik na etacie rządowym lub samorządowym potrafi godnie reprezentować państwo, prowincję, miasto czy też gminę.

Już 1 lutego 1852 r. Ministerstwo zakomunikowało egzaminatorom, że mają sprawdzać dojrzałość ducha abiturienta, a nie drugorzędne szczegóły. Przygotowując się do wprowadzenia egzaminu dojrzałości do szkół realnych, Ministerstwo w wydanym 9 maja 1872 r. rozporządzeniu przypomniało założenia Zarysu organizacyjnego..., że podczas egzaminu należy zbadać, czy zdający ma ogólny obraz oraz ogólny ogląd sytuacji i pozwolić mu to udowodnić. Codzienna praktyka często nie uwzględniała tych zaleceń. Uczniowie ostatniej klasy przez kilka miesięcy przygotowywali się do matury, powtarzając wiele razy szczegółowe definicje i formuły z poszczególnych przedmiotów. Dlatego Ministerstwo w wydanym 18 czerwca 1878 r. reskrypcie ponownie przywołało założenia Zarysu organizacyjnego..., że podczas matury należy kształtować dojrzałość ducha i samodzielność. Ten sam cel przyświecał resortowi oświaty, gdy wydawał 7 kwietnia 1899 r. rozporządzenie normujące egzamin dojrzałości w szkołach realnych, przypominając w nim zadania egzaminu końcowego i sposób jego przeprowadzania. Podobne zalecenia dla egzaminatorów powtórzone zostały w rozporządzeniu z 9 lutego 1908 r. i w kilku innych dyrektywach. W przytoczonych fragmentach rozporządzeń dostrzec można tę samą myśl przewodnią. Nasuwa się pytanie, dlaczego egzaminatorzy, którzy przecież byli kontrolowani przez swoich dyrektorów i inspektorów krajowych, rozmijali się z oczekiwaniami pomysłodawców matury. Można zakładać, że nie kierowali się złą wolą, ale sformułowanie takich pytań i zadań, które sprostałyby idealistycznym założeniom podczas egzaminu pisemnego i ustnego, było zadaniem bardzo trudnym.

Zarys organizacyjny... wprowadzał trzy terminy egzaminu dojrzałości: główny, zwany też letnim oraz dwa poboczne: jesienny i zimowy. W terminie letnim egzaminy miały odbywać się nie wcześniej niż dwa tygodnie przed zakończeniem roku szkolnego i nie później niż dwa tygodnie po jego zakończeniu. W 1908 r. okres ten skrócono i zakończenie matur miało następować nie później niż osiem dni po zakończeniu roku szkolnego. Przesuwanie tych terminów mogło nastąpić za zgodą Rady Szkolnej Krajowej. Termin jesienny nazywany był też wrześniowym, a zimowy - lutowym, chociaż bywały lata, że przeciągał się na marzec. Zdarzało się, że we wrześniu odbywały się dwa egzaminy: jeden poprawczy, a drugi normalny poboczny.

W praktyce z upływem lat okazało się, że terminy jesienny i zimowy służą abiturientom częściej do zdawania kilku przedmiotów niż całej matury. Z czasem termin poprawczy jesienny złączony został z pobocznym jesiennym. Natomiast termin zimowy w roku szkolnym 1886/87 został zlikwidowany. Kilkanaście lat później reaktywowano go, ale tylko dla zdających, którzy poprawiali jeden przedmiot. W 1903 r. termin ten przeznaczono na poprawki z jednego lub kilku przedmiotów, a w 1908 r. wrócono do pierwotnych rozwiązań i przywrócono trzy terminy egzaminu dojrzałości.

W terminie głównym, zwanym też letnim, część pisemna odbywała się trzy tygodnie przed ustną. Do 1908 r. część pisemna w każdym kraju monarchii habsburskiej 
organizowana była w tym samym terminie, wyznaczanym przez miejscową Radę Szkolną Krajową. Później termin egzaminu pisemnego wyznaczał dyrektor, ale uzależniony był od terminu ustnego, a ten ustalała Rada Szkolna Krajowa ${ }^{14}$.

Matura pisemna w szkołach realnych obejmowała: wypracowanie (zwane wtedy pracą klauzurową) w języku wykładowym, wypracowanie w języku państwowym, tj. niemieckim, przekład z języka niemieckiego na wykładowy lub odwrotnie, przekład z języka francuskiego na wykładowy, zadanie matematyczne oraz zadanie z geometrii wykreślnej. W Galicji w okresie autonomicznym językiem wykładowym we wszystkich szkołach realnych był polski ${ }^{15}$. Na wypracowanie z języka polskiego i zadania z geometrii wykreślnej przeznaczone było po pięć godzin, na wypracowanie z języka niemieckiego i zadania z matematyki po cztery godziny, na przekład z języka niemieckiego na polski (lub odwrotnie) oraz na przekład z języka francuskiego na polski - po trzy.

Natomiast w części ustnej uczniowie zdawali: jeden język, geografię i historię (stanowiły wtedy jeden przedmiot), matematykę, historię naturalną (przyrodę), fizykę oraz chemię. Podczas ustnej części w komisji zasiadali: przewodniczący, którym był zwykle krajowy inspektor szkół średnich lub delegat Rady Szkolnej Krajowej, dyrektor zakładu oraz wszyscy nauczyciele, którzy mieli zajęcia w klasie ostatniej, czyli siódmej $^{16}$. Matura miała charakter egzaminu publicznego, tak jak np. obrona pracy doktorskiej, a zatem mogły przysłuchiwać się jej osoby postronne, np. rodzice lub opiekunowie uczniów, abiturienci tego samego zakładu, przedstawiciele władz samorządowych, korporacji rzemieślniczych lub kupieckich oraz instytucji współpracujących ze szkołą, a także aplikanci i praktykanci przygotowujący się do zawodu nauczycielskiego ${ }^{17}$. W praktyce obserwatorzy niezwiązani z oświatą pojawiali się sporadycznie, na przykład podczas pierwszej matury organizowanej przez zakład, gdyż takie wydarzenie było wtedy świętem nie tylko placówki, ale także całego miasta.

W Galicji w drugiej połowie XIX i na początku XX w. funkcjonowało, krócej lub dłużej, 18 szkół realnych. Ilustruje to tabela 1.

Analizując tabelę, zauważyć można, że w trzech zakładach nie zdołano zorganizować egzaminu dojrzałości. Stało się tak, ponieważ Niższą Szkołę Realną w Brodach w 1865 r. zaczęto przekształcać w Niższe Gimnazjum, a proces ten trwał trzy lata. Lokalna społeczność nie zdołała przekształcić Miejskiej Szkoły Realnej w Śniatyniu w państwową i placówka ta w roku szkolnym 1872/73 przekształcona została w szkołę wydziałową ${ }^{18}$. W mieście tym udało się ponownie zorganizować szkołę realną dopiero po 30 latach. Natomiast Szkoła Realna w Rawie Ruskiej, mimo że powstała w 1909 r., na skutek perturbacji związanych z I wojną światową nie zdołała rozwinąć się do siedmioklasowej przed 1918 rokiem.

Trzy państwowe (cesarsko-królewskie) szkoły realne: w Stanisławowie, Stryju i Jarosławiu zorganizowane zostały na bazie miejskich szkół realnych. Dwie ostatnie nie funkcjonowały długo i zostały przekształcone w gimnazja - stryjska w latach 1880-1886, a jarosławska w latach 1884-1890. W Jarosławiu jednak po ośmiu la-

14 F. Bostel, Reforma egzaminu dojrzałości, „Muzeum” 1908, r. XXIV, t. 1, z. 4, s. 432-437.

15 W 1867 r. w Brodach i Tarnopolu wykładano po niemiecku, a we Lwowie i Śniatyniu po polsku.

16 Ustawy i rozporządzenia obowiązujące w galicyjskich..., s. 151-152.

17 S. Możdżeń, Ustrój szkoły średniej..., s. 24.

18 Ibidem, s. 127. 


\section{Tabela 1. Szkoły realne w Galicji}

\begin{tabular}{|c|c|c|c|c|c|}
\hline L.p. & Nazwa szkoły & $\begin{array}{c}\text { Dekret } \\
\text { założycielski }\end{array}$ & $\begin{array}{l}\text { Okres, w którym } \\
\text { funkcjonowała }\end{array}$ & $\begin{array}{c}\text { Pierwsza } \\
\text { matura }\end{array}$ & Informacje dodatkowe \\
\hline 1. & Sz.R. w Brodach & 14 I 1853 & $\begin{array}{c}1853 / 54- \\
1864 / 65\end{array}$ & - & $\begin{array}{l}\text { Powstała z istniejącej od } 1817 \\
\text { trzyklasowej Żydowskiej Sz.R.; } \\
\text { w } 1865 \text { przekształcona w Niższe } \\
\text { Gim. w Brodach }\end{array}$ \\
\hline 2. & $\begin{array}{l}\text { I Sz.R. we } \\
\text { Lwowie }\end{array}$ & 19 II 1856 & $\begin{array}{c}1856 / 57- \\
1920 / 21\end{array}$ & $1872 / 73$ & $\begin{array}{l}\text { Sz.R. we Lwowie powstała } \\
\text { w 1817, w latach 1845-1856 była } \\
\text { wcielona do Akademii Technicznej; } \\
\text { w 1921/22 przekształcona w I Gim. } \\
\text { we Lwowie }\end{array}$ \\
\hline 3. & $\begin{array}{l}\text { Sz.R. } \\
\text { w Tarnopolu }\end{array}$ & 26 VII 1858 & $\begin{array}{c}1858 / 59- \\
1920 / 21\end{array}$ & $1897 / 98$ & $\begin{array}{l}\text { 1921/22 przekształcona w III Gim. } \\
\text { w Tarnopolu }\end{array}$ \\
\hline 4. & Sz.R. w Śniatyniu & 1858 & $\begin{array}{l}\text { ok. } 1858 / 59- \\
1871 / 72\end{array}$ & - & $\begin{array}{l}\text { Szkoła miejska, w 1872/73 } \\
\text { przekształcona w szkołę } \\
\text { wydziałową }\end{array}$ \\
\hline 5. & $\begin{array}{l}\text { I Sz.R. } \\
\text { w Krakowie }\end{array}$ & 1 IX 1871 & $\begin{array}{c}1871 / 72- \\
1920 / 21\end{array}$ & $1873 / 74$ & $\begin{array}{l}\text { 1921/22 przekształcona w VIII } \\
\text { Gim. w Krakowie }\end{array}$ \\
\hline 6. & $\begin{array}{l}\text { Sz.R. } \\
\text { w Jarosławiu (I) }\end{array}$ & 10 IX 1872 & $\begin{array}{c}1872 / 73- \\
1889 / 90\end{array}$ & $1874 / 75$ & $\begin{array}{l}\text { W latach 1884/85-1889/90 } \\
\text { przekształcona w Gim. w Jarosławiu }\end{array}$ \\
\hline 7. & Sz.R. w Stryju & 9 XII 1872 & $\begin{array}{c}1872 / 73- \\
1885 / 86\end{array}$ & $1876 / 77$ & $\begin{array}{l}\text { W latach 1880/81-1885/86 } \\
\text { przekształcona w Gim. w Stryju }\end{array}$ \\
\hline 8. & $\begin{array}{l}\text { Sz.R. } \\
\text { w Stanisławowie }\end{array}$ & 8 V 1874 & $\begin{array}{c}1874 / 75- \\
1920 / 21\end{array}$ & $1877 / 78$ & $\begin{array}{l}\text { 1921/22 przekształcona w III Gim. } \\
\text { w Stanisławowie }\end{array}$ \\
\hline 9. & Sz.R. w Tarnowie & 7 VII 1897 & $\begin{array}{c}1897 / 98- \\
1920 / 21\end{array}$ & $1903 / 04$ & $\begin{array}{l}\text { 1921/22 przekształcona w III Gim. } \\
\text { w Tarnowie }\end{array}$ \\
\hline 10. & $\begin{array}{l}\text { Sz.R. } \\
\text { w Jarosławiu (II) }\end{array}$ & 27 VIII 1898 & $\begin{array}{c}1898 / 99- \\
1920 / 21\end{array}$ & $1904 / 05$ & $\begin{array}{l}\text { 1921/22 przekształcona w II Gim. } \\
\text { w Jarosławiu }\end{array}$ \\
\hline 11. & Sz.R. w Krośnie & 14 VIII 1900 & $\begin{array}{c}1900 / 01- \\
1920 / 21\end{array}$ & $1906 / 07$ & $\begin{array}{l}\text { 1921/22 przekształcona w Gim. } \\
\text { w Krośnie }\end{array}$ \\
\hline 12. & $\begin{array}{l}\text { II Sz.R. } \\
\text { w Krakowie }\end{array}$ & 11 VIII 1902 & $\begin{array}{c}1902 / 03- \\
1920 / 21\end{array}$ & $1902 / 03$ & $\begin{array}{l}\text { Powstała z Filii I Sz.R. w Krakowie; } \\
\text { w 1921/22 przekształcona w IX } \\
\text { Gim. w Krakowie }\end{array}$ \\
\hline 13. & $\begin{array}{l}\text { II Sz.R. we } \\
\text { Lwowie }\end{array}$ & 9V 1903 & $\begin{array}{c}1903 / 04- \\
1920 / 21\end{array}$ & $1904 / 05$ & $\begin{array}{l}\text { Powstała z Filii I Sz.R. we Lwowie, } \\
\text { w 1921/22 przekształcona w XI } \\
\text { Gim. we Lwowie }\end{array}$ \\
\hline 14. & Sz.R. w Śniatyniu & 2 VI 1903 & $\begin{array}{c}1903 / 04- \\
1920 / 21\end{array}$ & $1909 / 10$ & $\begin{array}{l}\text { 1921/22 przekształcona w Gim. } \\
\text { w Śniatyniu }\end{array}$ \\
\hline 15. & Sz.R. w Żywcu & 3 VIII 1904 & $\begin{array}{c}1904 / 05- \\
1920 / 21 \\
\end{array}$ & $1910 / 11$ & $\begin{array}{l}\text { 1921/22 przekształcona w Gim. } \\
\text { w Żywcu }\end{array}$ \\
\hline 16. & $\begin{array}{l}\text { Sz.R. } \\
\text { w Tarnobrzegu }\end{array}$ & 20 VIII 1909 & $\begin{array}{c}1909 / 10- \\
1920 / 21\end{array}$ & $1915 / 16$ & $\begin{array}{l}\text { 1921/22 przekształcona na Gim. } \\
\text { w Tarnobrzegu }\end{array}$ \\
\hline 17. & $\begin{array}{l}\text { Sz.R. w Rawie } \\
\text { Ruskiej }\end{array}$ & 10 VIII 1909 & $\begin{array}{c}1909 / 10- \\
1920 / 21\end{array}$ & $1919 / 20$ & $\begin{array}{l}\text { 1921/22 przekształcona w Gim. } \\
\text { w Rawie Ruskiej }\end{array}$ \\
\hline 18. & Sz.R. w Wieliczce & 27 VIII 1910 & $\begin{array}{c}1910 / 11- \\
1920 / 21\end{array}$ & $1916 / 17$ & $\begin{array}{l}\text { 1921/22 przekształcona w Gim. } \\
\text { w Wieliczce }\end{array}$ \\
\hline
\end{tabular}

Sz.R. - Szkoła Realna. Gim. - Gimnazjum

Źródło: Opracowano na podstawie informacji zawartych $w$ sprawozdaniach szkół realnych w Galicji za lata 1873/74-1920/21 oraz w Szematyzmach Królestwa Galicji i Lodomerii z Wielkim Księstwem Krakowskim za lata 1853-1914. 
tach ponownie zorganizowano od podstaw, tzn. od pierwszej klasy, nową szkołę realną, która przetrwała do początku lat dwudziestych XX wieku' ${ }^{19}$.

Najwięcej młodzieży uczęszczało do szkół realnych we Lwowie i w Krakowie. Gdy miały one po kilkanaście oddziałów i młodzież nie mieściła się w budynkach, przy obu tych placówkach zorganizowano filie. Po kilku latach usamodzielniły się one i w ten sposób, który wtedy nazywano pączkowaniem, powstały II Szkoła Realna we Lwowie i II Szkoła Realna w Krakowie ${ }^{20}$.

Spośród zakładów, które są przedmiotem niniejszego opracowania, najdłużej matura odbywała się w tych, które znajdowały się w dużych miastach: w I Szkole Realnej we Lwowie - 46 lat, w I Szkole Realnej w Krakowie - 45 lat, w Szkole Realnej w Stanisławowie - 41 lat i w Szkole Realnej w Tarnopolu - 21 lat. Natomiast najmniej egzaminów dojrzałości zorganizowano w Szkole Realnej w Wieliczce - dwa, w Szkole Realnej w Tarnobrzegu - trzy i w Szkole Realnej w Żywcu - osiem².

Zarys organizacyjny... z 1849 r. i późniejsze jego modyfikacje bardzo precyzyjnie opisywały wszystkie kwestie organizacyjne związane z maturą, tzn. zasady dotyczące egzaminów składanych w trybie normalnym i trybie poprawkowym, w terminie letnim, jesiennym i zimowym. W okresie I wojny światowej pojawiły się jeszcze terminy: wojenny i przyspieszony. Dokument ten zakreślał ramy czasowe, których nie można było przekroczyć przy wszystkich rodzajach egzaminów. Opisywał wymagania z poszczególnych przedmiotów w części pisemnej i ustnej. Określał zasady pracy i uprawnienia komisji oraz jej członków, a także sposób ustalania ocen z poszczególnych przedmiotów. Podawał normy dotyczące sporządzania dokumentacji w trakcie egzaminów i po ich zakończeniu. Ustalał zasady i terminy wydawania świadectw dla uczniów, którzy nie podchodzili do matury i dla tych, którzy zdawali ją w różnym trybie. Określał, jakie adnotacje należy zamieszczać na dyplomie dojrzałości. Przewidywał też zasady odwoływania się od wyników do Rady Szkolnej Krajowej i Ministerstwa Wyznań i Oświaty w przypadkach, w których procedura zostałaby naruszona. Regulował sposób zdawania egzaminu poza macierzystą placówką. Z czasem pojawiły się przepisy dotyczące eksternistów i prywatystów, a pod koniec XIX w. - reguły określające warunki dopuszczania do matury dziewcząt. Zarówno te przykładowo wymienione regulacje, jak i inne ulegały dość częstym zmianom ${ }^{22}$. Urzędnikami odpowiedzialnymi za całokształt przygotowań i za prawidłowy przebieg egzaminu dojrzałości byli dyrektorzy szkół realnych, a w okresach przejściowych zastępcy dyrektorów, zwani też kierownikami. Ich imienny wykaz przedstawia tabela 2.

Jak wynika z zamieszczonego zestawienia, w latach 1872/73-1917/18 w galicyjskich szkołach realnych maturę przygotowywało i organizowało 45 dyrektorów i kierowników. Artur Passendorfer czynił to w trzech zakładach: I Szkole Realnej we Lwowie, Szkole Realnej w Tarnopolu i II Szkole Realnej we Lwowie, Michał Rembacz - w dwóch placówkach: I Szkole Realnej we Lwowie i Szkole Realnej w Tarnopolu, Józef Trojnar - także w dwóch: II Szkole Realnej we Lwowie i Szkole Realnej w Tarno-

19 Informacje na podstawie analizy tabeli 1 oraz sprawozdań galicyjskich szkół realnych za lata 1875/76-1920/21.

20 T. Ochenduszko, M. Świętoń, Filie galicyjskich szkół średnich $w$ drugiej połowie XIX i na początku XX wieku, [w:] Spr. Dyr. I Gim. w Rzeszowie za r. szk. 2018/19, s. 30-32.

${ }_{21}$ Informacje na podstawie analizy tabeli 1 oraz sprawozdań galicyjskich szkół realnych.

22 Ustawy i rozporządzenia obowiq̨zujq̨ce w galicyjskich..., s. 74-83, 151-153. 
Tadeusz Ochenduszko

Tabela 2. Organizatorzy egzaminów dojrzałości w galicyjskich szkołach realnych

\begin{tabular}{|c|c|c|c|}
\hline L.p. & Nazwa szkoły & Organizator matury & Lata \\
\hline 1. & I Sz.R. we Lwowie & $\begin{array}{l}\text { Czesław Rodecki } \\
\text { Karol Benoni (k) } \\
\text { Teofil Gerstmann } \\
\text { Artur Passendorfer (k) } \\
\text { Michał Rembacz } \\
\text { Władysław Żłobicki (k) } \\
\text { Julian Mazurek (k) } \\
\text { Julian Mazurek }\end{array}$ & $\begin{array}{l}1872 / 73-\text { II } 1889 \\
\text { II - VI 1889 } \\
1889 / 90-1905 / 06 \\
1906 / 07 \\
1907 / 08-1913 / 14 \\
1915 / 16 \\
\text { VII } 1916-\text { VI } 1917 \\
1917 / 18\end{array}$ \\
\hline 2. & Sz.R. w Tarnopolu & $\begin{array}{l}\text { Michał Rembacz } \\
\text { Artur Passendorfer } \\
\text { Józef Lehmann (k) } \\
\text { Józef Trojnar }\end{array}$ & $\begin{array}{l}\text { 1897/98-1906/07 } \\
1907 / 08-1911 / 12 \\
\text { X 1912- IV } 1913 \\
\text { IV 1913-1917/18 }\end{array}$ \\
\hline 3. & I Sz.R. w Krakowie & $\begin{array}{l}\text { Marceli Studziński } \\
\\
\text { Jan Mazurkiewicz (k) } \\
\text { Jan Lenartowicz (k) } \\
\text { Ludomił German (k) } \\
\text { Alojzy Szarłowski (k) } \\
\text { Hugo Zathey } \\
\text { Roman Spritzer (k) } \\
\text { Ignacy Petelenz } \\
\text { Roman Spritzer (k) } \\
\text { Kajetan Kosiński (k) } \\
\text { Walerian Krywult (k) } \\
\text { Jan Dziurzyński (k) } \\
\text { Jan Dziurzyński }\end{array}$ & $\begin{array}{l}\text { 1873/74 - III } 1878 \\
\text { i 1886/87 - XII } 1888 \\
\text { IV } 1878 \text { - I } 1882 \\
\text { II } 1882-1885 / 86 \\
\text { I - V } 1889 \\
\text { V - VII } 1889 \\
1889 / 90 \text { - III } 1896 \\
\text { III - VII 1896 } \\
\text { 1896/97-1900/01 } \\
\text { 1901/02-1902/03 } \\
1903 / 04-\text { X } 1907 \\
\text { X } 1907-\text { VII } 1908 \\
1908 / 09-\text { II } 1912 \\
\text { II 1912-1917/18 }\end{array}$ \\
\hline 4. & Sz.R. w Jarosławiu (I) & Andrzej May & I 1879-1889/90 \\
\hline 5. & Sz.R. w Stryju & Erazm Misiński & $1876 / 77-1885 / 86$ \\
\hline 6. & Sz.R. w Stanisławowie & $\begin{array}{l}\text { Edward Hückel } \\
\text { Józef Czaczkowski } \\
\text { Franciszek Nowosielski }\end{array}$ & $\begin{array}{l}1877 / 78-1878 / 79 \\
1879 / 80-1898 / 99 \\
1899-1917 / 18\end{array}$ \\
\hline 7. & Sz.R. w Tarnowie & Karol Trochanowski & 1903/04-1917/18 \\
\hline 8. & Sz.R. w Jarosławiu (II) & $\begin{array}{l}\text { Michał Gonet (k) } \\
\text { Jan Ralski } \\
\text { Walenty Litwin (k) }\end{array}$ & $\begin{array}{l}\text { 1904/05 } \\
1905 / 06-1917 / 18 \\
\text { III - VII } 1916\end{array}$ \\
\hline 9. & Sz.R. w Krośnie & Kasper Brzostowicz & $1906 / 07-1917 / 18$ \\
\hline 10. & II Sz.R. w Krakowie & $\begin{array}{l}\text { Jan Bidziński } \\
\text { Józef Pizło (k) } \\
\text { Stanisław Sobiński (k) } \\
\text { Aleksander Jaworski (k) } \\
\end{array}$ & $\begin{array}{l}1904 / 05-1906 / 07 \\
\text { i 1908/09- IX } 1917 \\
\text { IX - XII 1907 } \\
\text { XII 1907 - VII } 1908 \\
1917 / 18\end{array}$ \\
\hline 11. & II Sz.R. we Lwowie & $\begin{array}{l}\text { Jan Lityński } \\
\text { Józef Trojnar (k) } \\
\text { Artur Passendorfer }\end{array}$ & $\begin{array}{l}\text { 1904/05-1909/10 } \\
\text { IX 1910- XI 1911 } \\
1912 / 13-1913 / 14 \\
\text { i 1915/16-1917/18 } \\
\end{array}$ \\
\hline 12. & Sz.R. w Śniatyniu & $\begin{array}{l}\text { Cezary Hołubowicz } \\
\text { ks. Michał Borowy (k) }\end{array}$ & $\begin{array}{l}\text { 1911/12 - II } 1914 \\
\text { II - VII } 1914\end{array}$ \\
\hline 13. & Sz.R. w Żywcu & $\begin{array}{l}\text { Bronisław Gustawicz } \\
\text { Szczęsny Gizowski (k) } \\
\text { Antoni Waśniowski } \\
\text { Jan Kreiner (k) } \\
\text { Bronisław Duchowicz }\end{array}$ & $\begin{array}{l}\text { 1910/11 - IX } 1912 \\
\text { IX 1912 - III 1913 } \\
\text { IV 1913-1913/14 } \\
\text { IX 1914 - IX 1915 } \\
\text { IX 1915-1916/17 }\end{array}$ \\
\hline
\end{tabular}




\begin{tabular}{|l|l|l|l|}
\hline L.p. & \multicolumn{1}{|c|}{ Nazwa szkoły } & \multicolumn{1}{c|}{ Organizator matury } & \multicolumn{1}{c|}{ Lata } \\
\hline 14. & Sz.R. w Tarnobrzegu & $\begin{array}{l}\text { Stanisław Sobiński } \\
\text { Karol Adwentowski (k) } \\
\text { Józef Lamber }\end{array}$ & $\begin{array}{l}\text { 1915/16-1916/17 } \\
\text { IV IV 1918 } \\
\text { IV - VII 1918 }\end{array}$ \\
\hline 15. & Sz.R. w Wieliczce & Wiktor Pogorzelski & $1916 / 17-1917 / 18$ \\
\hline
\end{tabular}

Sz.R. - Szkoła Realna. (k) - kierownik

Źródło: Opracowanie własne na podstawie informacji zawartych $w$ sprawozdaniach szkół realnych w Galicji za lata 1873/74-1917/18 oraz w Szematyzmach Królestwa Galicji i Lodomerii z Wielkim Księstwem Krakowskim za lata 1872-1914.

polu, Stanisław Sobiński również w dwóch: w II Szkole Realnej w Krakowie i Szkole Realnej w Tarnobrzegu, natomiast pozostali - w jednym zakładzie.

Najdłużej, bo 21 lat, organizatorem matur był dyrektor Szkoły Realnej w Stanisławowie Józef Czaczkowski. Tylko o rok krócej zabezpieczał prawidłowy przebieg egzaminów dojrzałości jego następca, Franciszek Nowosielski. Przez 17 lat czuwał nad końcowymi egzaminami dyrektor I Szkoły Realnej we Lwowie Czesław Rodecki. Dorównał mu Michał Rembacz, organizując egzaminy najpierw przez 10 lat we Lwowie, a później przez 7 lat w Tarnopolu.

Spośród zarządców szkół realnych dwudziestu organizowało matury w randze dyrektora i tyluż w randze kierownika, natomiast czterech najpierw pełniło funkcję kierownika, a później dyrektora. Byli to: Stanisław Sobiński (w II Szkole Realnej w Krakowie i Szkole Realnej w Tarnobrzegu), Józef Trojnar (w II Szkole Realnej we Lwowie i Szkole Realnej w Tarnopolu), Julian Mazurek (obie funkcje w I Szkole Realnej we Lwowie) i Jan Dziurzyński (obie funkcje w I Szkole Realnej w Krakowie). Natomiast Artur Passendorfer raz był kierownikiem (w I Szkole Realnej we Lwowie), a dwa razy dyrektorem (w Szkole Realnej w Tarnopolu i II Szkole Realnej we Lwowie). W dwóch placówkach w roli dyrektora występował Michał Rembacz (w Szkole Realnej w Tarnopolu i I Szkole Realnej we Lwowie) ${ }^{23}$.

Dyrektorzy i kierownicy, którzy organizowali matury w szkołach realnych, byli osobami znanymi i szanowanymi nie tylko w swoich środowiskach, ale także w całej Galicji. Warto zwrócić uwagę, że spośród nich na inspektorów szkolnych awansowali: Edward Hückel, Michał Rembacz i Ludomił German. Marceli Studziński został delegatem miasta Krakowa do Rady Szkolnej Krajowej. Natomiast Stanisław Sobiński, który w 1918 r. był wizytatorem szkolnym w znajdującym się pod kontrolą Niemiec i Austro-Węgier Królestwie Polskim, po odzyskaniu przez Polskę niepodległości został prezydentem Rady Szkolnej Krajowej oraz delegatem Ministerstwa Wyznań Religijnych i Oświecenia Publicznego na obszar byłej Galicji, a później pierwszym kuratorem Okręgu Szkolnego Lwowskiego. Ignacy Petelenz łączył pracę w I Szkole Realnej w Krakowie z działalnością naukową w Lwowskiej Szkole Politechnicznej oraz działalnością społeczno-polityczną w Radzie Miasta Krakowa i w Radzie Państwa w Wiedniu. Kasper Brzostowicz i Władysław Żłobicki popularyzowali wiedzę o elektryczności. Karol Trochanowski zaś zyskał uznanie społeczne jako odkrywca źródeł mineralnych, m.in. w Wysowej, Iwoniczu i Krościenku ${ }^{24}$.

23 Informacje na podstawie analizy tabeli 2.

24 Polski Słownik Biograficzny [dalej: PSB], t. VII/1, s. 396-398; T. Ochenduszko, Leksykon 
Matura w szkołach realnych, podobnie jak w gimnazjach, była egzaminem państwowym, zatem abiturienci zdawali ją przed komisją państwową, tj. cesarsko-królewską. Jak już wspomniano, w części pisemnej zwykle przewodniczył dyrektor szkoły lub kierownik, a w części ustnej - krajowy inspektor szkolny lub delegat Rady Szkolnej Krajowej. Na początku lat siedemdziesiątych XIX w. inspektorów szkół średnich było dwóch. Jednemu podlegały zakłady w Galicji Zachodniej, a drugiemu we Wschodniej. W 1886 r. ich liczba wzrosła do trzech. Natomiast w latach 1892-1895 nastąpiła reorganizacja, w wyniku której inspektorzy szkół średnich zajęli się wyłącznie gimnazjami, a nadzór nad szkołami realnymi, przemysłowymi i handlowymi przekazano jednemu wspólnemu inspektorowi ${ }^{25}$.

Inspektorów szkolnych było za mało w stosunku do zadań, które im zostały przydzielone i nie byli w stanie przewodniczyć wszystkim egzaminom dojrzałości. Dlatego Rada Szkolna Krajowa kierowała do części szkół swoich delegatów. W sprawozdaniach szkolnych zachowały się informacje dotyczące przewodniczących matur ustnych z 213 egzaminów ${ }^{26}$. Warto zatem przyjrzeć się funkcjom urzędników, którzy nadzorowali, aby społeczny status inteligenta, jaki dawała wtedy matura, uzyskiwany był w zgodzie z literą i duchem przepisów oświatowych. Ilustruje to tabela 3.

Ustnym egzaminom dojrzałości przewodniczyło 33 urzędników oświatowych. Jedni funkcję przewodniczącego pełnili kilka razy, inni kilkanaście lub kilkadziesiąt. Na czele 213 egzaminów zorganizowanych w różnych szkołach stało 231 przewodniczących (lub współprzewodniczących). Ta nadwyżka 18 przewodniczących wynikła z dwóch powodów. Zdarzało się, że w zakładach, w których była większa liczba uczniów i klasy siódme były podzielone na dwa oddziały, aby przyspieszyć maturę, odpowiedzialny za nią inspektor lub delegat RSK dzielił zdających na dwie grupy, sam przewodniczył egzaminowi w jednej, a nadzór nad drugą powierzał dyrektorowi szkoły. Rozwiązanie takie zastosowano m.in. w I Szkole Realnej w Krakowie w latach 1903/04-1904/05 i w I Szkole Realnej we Lwowie okresie 1903/04-1907/08. Czasami wysyłano do jednego zakładu na jeden egzamin ustny odbywający się przed dwiema komisjami dwóch delegatów RSK. Usprawnienie takie zastosowano na przykład w II Szkole Realnej we Lwowie w latach 1909/10-1910/11. Bywało też, że jeżeli matura ustna trwała kilka dni, inspektor przewodniczył jej dzień lub dwa, a później jego rolę przejmował delegat RSK, ewentualnie dyrektor. Zdarzyło się tak m.in. w I Szkole Realnej we Lwowie w latach 1909/10-1911/12.

Krajowy inspektor szkolny najczęściej odwiedzał podległe mu placówki przy okazji egzaminów dojrzałości, wizytacji, które wtedy nazywano lustracjami, pożegnań zasłużonych pedagogów, którzy przechodzili w stan spoczynku, ewentualnie z okazji świąt i ważnych uroczystości. Lustracje odbywały się zwykle co dwa lata. Jeżeli w danym roku szkolnym inspektor zlustrował szkołę, to na jego wniosek RSK

kadry kierowniczej gimnazjów galicyjskich w okresie autonomii, Rzeszów 2015, s. 40-41, 104-106, 134-135; idem, Władysław Żłobicki - pedagog, urzędnik oświatowy, elektryk, „Maszyny Elektryczne - Zeszyty Problemowe”, nr 4/2017 (116), Katowice 2017, s. 191-196; A. Błahut, T. Ochenduszko, Kasper Brzostowicz - pedagog, dyrektor szkoły, elektryk, „Maszyny Elektryczne - Zeszyty Problemowe", nr 4/2016 (112), Katowice 2016, s. 13-18.

25 T. Ochenduszko, Rada Szkolna Krajowa we Lwowie, [w:] Spr. Dyr. I Lic. w Rzeszowie za r. szk. 2013/14, Rzeszów 2014, s. 14, 18.

26 W sprawozdaniach I Szkoły Realnej we Lwowie w latach 1872/73-1884/85 nie zamieszczano informacji, kto był przewodniczącym komisji przy egzaminie maturalnym ustnym. 
Tabela 3. Przewodniczący komisji egzaminów dojrzałości w galicyjskich szkołach realnych

\begin{tabular}{|c|c|c|c|c|}
\hline L.p. & $\begin{array}{l}\text { Nazwa } \\
\text { szkoły }\end{array}$ & $\begin{array}{l}\text { Przewodniczący komisji } \\
\text { podczas letniego egza- } \\
\text { minu ustnego }\end{array}$ & Funkcja & Lata \\
\hline \multirow[t]{10}{*}{1.} & \multirow{10}{*}{$\begin{array}{l}\text { I Sz.R. we } \\
\text { Lwowie }\end{array}$} & Edward Hückel & Krajowy inspektor szkół & 1885/86-1886/87 \\
\hline & & Władysław Zajączkowski & Delegat RSK & 1887/88-1888/89 \\
\hline & & Bronisław Radziszewski & Delegat RSK & $1889 / 90$ \\
\hline & & Jan Franke & $\begin{array}{l}\text { Delegat RSK } \\
\text { Krajowy inspektor szkół }\end{array}$ & $\begin{array}{l}1890 / 91 \\
1891 / 92-1901 / 02, \\
1909 / 10-1913 / 14\end{array}$ \\
\hline & & Placyd Dziwiński & Delegat RSK & $1903 / 04$ \\
\hline & & Michał Rembacz & $\begin{array}{l}\text { Delegat RSK } \\
\text { Krajowy inspektor szkół }\end{array}$ & $\begin{array}{l}\text { 1902/03-1905/06, } \\
1916 / 17\end{array}$ \\
\hline & & Tadeusz Fiedler & Delegat RSK & 1905/06-1908/09 \\
\hline & & Antoni Stefanowicz & Krajowy inspektor szkół & $\begin{array}{l}\text { 1906/07-1907/08, } \\
1911 / 12\end{array}$ \\
\hline & & Władysław Żłobicki & Delegat RSK & $1913 / 14$ \\
\hline & & Julian Mazurek & Kierownik zakładu & $1917 / 18$ \\
\hline \multirow[t]{8}{*}{2.} & \multirow[t]{8}{*}{$\begin{array}{l}\text { Sz.R.w Tar- } \\
\text { nopolu }\end{array}$} & Jan Franke & Krajowy inspektor szkół & $\begin{array}{l}1897 / 98-1898 / 99, \\
1900 / 01-1904 / 05, \\
1906 / 07,1908 / 09\end{array}$ \\
\hline & & Teofil Gerstman & Delegat RSK & $1899 / 1900$ \\
\hline & & Franciszek Nowosielski & Delegat RSK & $1905 / 06$ \\
\hline & & Michał Rembacz & Delegat RSK & $\begin{array}{l}\text { 1907/08, 1909/10, } \\
1913 / 14\end{array}$ \\
\hline & & Artur Passendorfer & Dyrektor zakładu & 1908 \\
\hline & & Jan Ralski & Delegat RSK & $1910 / 11$ \\
\hline & & Franciszek Nowosielski & Delegat RSK & $1911 / 12$ \\
\hline & & Józef Trojnar & Dyrektor zakładu & $1912 / 13$ \\
\hline \multirow[t]{10}{*}{3.} & \multirow{10}{*}{$\begin{array}{l}\text { I Sz.R. } \\
\text { w Krakowie }\end{array}$} & Edward Hückel & Krajowy inspektor szkół & $1876 / 77-1877 / 78$ \\
\hline & & Marceli Studziński & Dyrektor zakładu & $\begin{array}{l}1878 / 79,1881 / 82- \\
1885 / 86\end{array}$ \\
\hline & & Władysław Zajączkowski & Delegat RSK & 1887/88-1888/89 \\
\hline & & Ludomił German & Krajowy inspektor szkół & $1889 / 90$ \\
\hline & & Jan Franke & Krajowy inspektor szkół & $\begin{array}{l}\text { 1890/91-1902/03, } \\
\text { 1909/10-1910/11, } \\
1912 / 13-1913 / 14\end{array}$ \\
\hline & & August Witkowski & Delegat RSK & $\begin{array}{l}\text { 1903/04-1904/05, } \\
1908 / 09\end{array}$ \\
\hline & & Jan Bidziński & Delegat RSK & 1905/06, \\
\hline & & Kazimierz Żórawski & Delegat RSK & $\begin{array}{l}\text { 1906/07-1907/08, } \\
1911 / 12,1915 / 16\end{array}$ \\
\hline & & Jan Dziurzyński & Dyrektor zakładu & $1912 / 13$ \\
\hline & & Michał Rembacz & Krajowy inspektor szkół & $\begin{array}{l}\text { 1914/15, 1916/17- } \\
1917 / 18\end{array}$ \\
\hline
\end{tabular}




\begin{tabular}{|c|c|c|c|c|}
\hline L.p. & $\begin{array}{l}\text { Nazwa } \\
\text { szkoły }\end{array}$ & $\begin{array}{l}\text { Przewodniczący komisji } \\
\text { podczas letniego egza- } \\
\text { minu ustnego }\end{array}$ & Funkcja & Lata \\
\hline \multirow[t]{5}{*}{4.} & \multirow[t]{5}{*}{$\begin{array}{l}\text { Sz.R. w Ja- } \\
\text { rosławiu (I) }\end{array}$} & Edward Hückel & $\begin{array}{l}\text { Delegat RSK } \\
\text { Krajowy inspektor szkół }\end{array}$ & $\begin{array}{l}1878 / 79 \\
1884 / 85-1886 / 87\end{array}$ \\
\hline & & Antoni Czarkowski & Krajowy inspektor szkół & $1879 / 80$ \\
\hline & & Marceli Studziński & Delegat RSK & $1880 / 81-1883 / 84$ \\
\hline & & Władysław Zajączkowski & Delegat RSK & $1887 / 88-1888 / 89$ \\
\hline & & Ludomił German & Krajowy inspektor szkół & $1889 / 90$ \\
\hline \multirow[t]{2}{*}{5.} & \multirow{2}{*}{$\begin{array}{l}\text { Sz.R. } \\
\text { w Stryju }\end{array}$} & Antoni Sołtykiewicz & Krajowy inspektor szkół & 1876/77-1883/84 \\
\hline & & Edward Hückel & Krajowy inspektor szkół & $1884 / 85$ \\
\hline \multirow[t]{7}{*}{6.} & \multirow{7}{*}{$\begin{array}{l}\text { Sz.R. w Sta- } \\
\text { nisławowie }\end{array}$} & Antoni Sołtykiewicz & Krajowy inspektor szkół & 1877/78-1888/89 \\
\hline & & Bronisław Radziszewski & Delegat RSK & $1889 / 90$ \\
\hline & & Jan Franke & $\begin{array}{l}\text { Delegat RSK } \\
\text { Krajowy inspektor szkół }\end{array}$ & $\begin{array}{l}1890 / 91 \\
1891 / 92-1903 / 04 \\
1905 / 06,1907 / 08\end{array}$ \\
\hline & & Teofil Gerstmann & Delegat RSK & $1904 / 05$ \\
\hline & & Michał Rembacz & Delegat RSK & $\begin{array}{l}\text { 1906/07, 1908/09, } \\
1910 / 11-1911 / 12\end{array}$ \\
\hline & & Antoni Stefanowicz & Krajowy inspektor szkół & $1909 / 10$ \\
\hline & & Franciszek Nowosielski & Dyrektor zakładu & $1915 / 16$ \\
\hline \multirow[t]{7}{*}{7.} & \multirow[t]{7}{*}{$\begin{array}{l}\text { Sz.R. w Tar- } \\
\text { nowie }\end{array}$} & Jan Franke & Krajowy inspektor szkół & $\begin{array}{l}\text { 1903/04-1905/06, } \\
1907 / 08-1908 / 09\end{array}$ \\
\hline & & Karol Trochanowski & Dyrektor zakładu & $\begin{array}{l}\text { 1912/13-1913/14, } \\
1917 / 18\end{array}$ \\
\hline & & Jan Bidziński & Delegat RSK & $1906 / 07,1910 / 11$ \\
\hline & & Bronisław Gustawicz & Delegat RSK & $1909 / 10$ \\
\hline & & Stanisław Sobiński & Delegat RSK & $1911 / 12$ \\
\hline & & Michał Rembacz & Krajowy inspektor szkół & $1915 / 16$ \\
\hline & & Bronisław Duchowicz & Delegat RSK & $1916 / 17$ \\
\hline \multirow[t]{8}{*}{8.} & \multirow{8}{*}{$\begin{array}{l}\text { Sz.R. w Ja- } \\
\text { rosławiu } \\
\text { (II) }\end{array}$} & Jan Franke & Krajowy inspektor szkół & $\begin{array}{l}1904 / 05-1906 / 07 \\
1908 / 09\end{array}$ \\
\hline & & Artur Passendorfer & Delegat RSK & $1907 / 08,1909 / 10$ \\
\hline & & Kasper Brzostowicz & Delegat RSK & $1910 / 11$ \\
\hline & & Karol Trochanowski & Delegat RSK & $1911 / 12$ \\
\hline & & Jan Ralski & Dyrektor zakładu & $1912 / 13,1917 / 18$ \\
\hline & & Bronisław Duchowicz & Delegat RSK & $1913 / 14$ \\
\hline & & ks. Walenty Litwin & Kierownik zakładu & 1915-1916 \\
\hline & & Michał Rembacz & Krajowy inspektor szkół & 1915/16-1916/17 \\
\hline \multirow[t]{5}{*}{9.} & \multirow{5}{*}{$\begin{array}{l}\text { Sz.R. w Kro- } \\
\text { śnie }\end{array}$} & Jan Franke & Krajowy inspektor szkół & 1906/07-1907/08 \\
\hline & & Artur Passendorfer & Delegat RSK & $1908 / 09$ \\
\hline & & Stanisław Sobiński & Delegat RSK & 1909/10-1910/11 \\
\hline & & Jan Ralski & Delegat RSK & $1911 / 12$ \\
\hline & & Kasper Brzostowicz & Dyrektor zakładu & $\begin{array}{l}\text { 1912/13, 1915/16- } \\
1917 / 18\end{array}$ \\
\hline
\end{tabular}




\begin{tabular}{|c|c|c|c|c|}
\hline L.p. & $\begin{array}{l}\text { Nazwa } \\
\text { szkoły }\end{array}$ & $\begin{array}{l}\text { Przewodniczący komisji } \\
\text { podczas letniego egza- } \\
\text { minu ustnego }\end{array}$ & Funkcja & Lata \\
\hline \multirow[t]{7}{*}{10.} & \multirow[t]{7}{*}{$\begin{array}{l}\text { II Sz.R. } \\
\text { w Krakowie }\end{array}$} & Jan Franke & Krajowy inspektor szkół & $\begin{array}{l}\text { 1904/05-1907/08, } \\
1911 / 12\end{array}$ \\
\hline & & Jan Bidziński & Dyrektor zakładu & $1908 / 09,1912 / 13$ \\
\hline & & Kazimierz Żórawski & Delegat RSK & $\begin{array}{l}\text { 1909/10-1910/11, } \\
1915 / 16-1916 / 17\end{array}$ \\
\hline & & Józef Pizło & Kierownik zakładu & $1907 / 08$ \\
\hline & & Michał Rembacz & Krajowy inspektor szkół & $1913 / 14$ \\
\hline & & Aleksander Jaworski & Kierownik zakładu & $1917 / 18$ \\
\hline & & Jan Dziurzyński & Delegat RSK & $1917 / 18$ \\
\hline \multirow[t]{6}{*}{11.} & \multirow[t]{6}{*}{$\begin{array}{l}\text { II Sz.R. we } \\
\text { Lwowie }\end{array}$} & Jan Franke & Krajowy inspektor szkół & $\begin{array}{l}\text { 1904/05-1908/09, } \\
1911 / 12\end{array}$ \\
\hline & & Antoni Stefanowicz & Krajowy inspektor szkół & $1908 / 09$ \\
\hline & & Tadeusz Fiedler & Delegat RSK & $1909 / 10$ \\
\hline & & Zdzisław Krygowski & Delegat RSK & $1909 / 10$ \\
\hline & & Artur Passendorfer & Dyrektor zakładu & 1912/13-1915/16 \\
\hline & & Placyd Dziwiński & Delegat RSK & $1916 / 17$ \\
\hline \multirow[t]{3}{*}{12.} & \multirow{3}{*}{$\begin{array}{l}\text { Sz.R. } \\
\text { w Śniatyniu }\end{array}$} & Artur Passendorfer & Delegat RSK & $1911 / 12$ \\
\hline & & Antoni Stefanowicz & Krajowy inspektor szkół & $1912 / 13$ \\
\hline & & Władysław Żłobicki & Delegat RSK & $1913 / 14$ \\
\hline \multirow[t]{5}{*}{13.} & \multirow{5}{*}{$\begin{array}{l}\text { Sz.R. } \\
\text { w Żywcu }\end{array}$} & Jan Franke & Krajowy inspektor szkół & $1910 / 11$ \\
\hline & & Jan Dziurzyński & Delegat RSK & $\begin{array}{l}\text { 1911/12, 1913/14, } \\
1915 / 16\end{array}$ \\
\hline & & Antoni Waśniowski & Dyrektor zakładu & $1912 / 13$ \\
\hline & & Michał Rembacz & Delegat RSK & $1914 / 15$ \\
\hline & & Bronisław Duchowicz & Delegat RSK & 1915/16-1916/17 \\
\hline 14. & $\begin{array}{l}\text { Sz.R. w Tar- } \\
\text { nobrzegu }\end{array}$ & Stanisław Sobiński & Dyrektor zakładu & 1915/16-1916/17 \\
\hline \multirow[t]{2}{*}{15.} & \multirow{2}{*}{$\begin{array}{l}\text { Sz.R. } \\
\text { w Wieliczce }\end{array}$} & Jan Bidziński & Delegat RSK & $1916 / 17$ \\
\hline & & Michał Rembacz & Krajowy inspektor szkół & $1917 / 18$ \\
\hline
\end{tabular}

\section{Sz.R. - Szkoła Realna}

RSK - Rada Szkolna Krajowa

Lata, w których brak danych, nie zostały ujęte w tabeli.

Źródło: Opracowanie własne na podstawie informacji zawartych w sprawozdaniach szkół realnych w Galicji za lata 1873/74-1917/18 oraz w Szematyzmach Królestwa Galicji i Lodomerii z Wielkim Księstwem Krakowskim za lata 1873-1914.

powierzała nadzór nad maturą delegatowi, ewentualnie dyrektorowi lub kierownikowi zakładu. Tak było na przykład w I Szkole Realnej we Lwowie w roku 1890/91.

$\mathrm{Z}$ reguły nadzór nad maturą w terminach jesiennym i zimowym sprawował dyrektor szkoły. Zdarzało się, że pojawiał się inspektor. Jeśli nie stwierdził uchybień, 
a abiturienci wypadli dobrze, to swoje zadania z terminu letniego zlecał dyrektorowi. Rozwiązanie takie zastosowane zostało m.in. w I Szkole Realnej we Lwowie w latach 1888/89-1890/91 i w II Szkole Realnej w Krakowie w latach 1908/09 i 1912/13.

Spośród przewodniczących w 213 komisjach nadzorujących egzamin ustny w terminie letnim inspektorzy stanowili 54,55\%, delegaci RSK - 30,71\%, dyrektorzy placówek, w których odbywał się egzamin - 13\%, a kierownicy $-1,74 \%{ }^{27}$.

Inspektorami krajowymi szkół, którzy przewodniczyli komisjom podczas części ustnej egzaminów dojrzałości w szkołach realnych, byli: Antoni Czarkowski, Antoni Sołtykiewicz, Edward Hückel, Ludomił German, Jan Franke, Antoni Stefanowicz i Michał Rembacz. Czarkowski, Sołtytkiewicz, Hückel i German mieli w przydziale swoich obowiązków opiekę nad szkołami średnimi, natomiast Franke, Rembacz i Stefanowicz - nadzór nad szkołami realnymi i zawodowymi, a Stefanowiczowi powierzono ponadto opiekę nad nauką rysunków. Najaktywniejszym z nich był Jan Nepomucen Franke, który przewodniczył komisjom maturalnym 73 razy jako inspektor i raz jako delegat RSK ${ }^{28}$. Najbardziej znanym, ze względu na swoją działalność polityczną, był Ludomił German. Reprezentował on interesy Galicji w Sejmie Krajowym we Lwowie (IX i X kadencji) i w Radzie Państwa w Wiedniu (1907-1918), podczas I wojny światowej był członkiem Naczelnego Komitetu Narodowego, działał na rzecz powiązania polskiego interesu narodowego z Austro-Węgrami. Michał Rembacz nie przyjął propozycji objęcia Katedry Geometrii Wykreślnej na Politechnice Lwowskiej, wybierając służbę w Radzie Szkolnej Krajowej, a następnie w Kuratorium Okręgu Szkolnego Lwowskiego. Jan Nepomucen Franke, na prośbę wiceprezydenta Rady Szkolnej Krajowej Michała Bobrzyńskiego, porzucił Katedrę Mechaniki i Teorii Maszyn na Politechnice Lwowskiej, by w 1892 r. stanąć na czele utworzonej przy RSK Sekcji Szkół Zawodowych, Realnych i Przemysłowych. Organizował i wspierał szkoły przemysłowe oraz działał w Krajowej Komisji Przemysłowej. Z kolei Edward Hückel to ceniony botanik i pedagog, autor prac florystycznych i podręcznika do botaniki dla gimnazjów i szkół realnych. Antoni Stefanowicz zaś dał się poznać nie tylko jako inspektor rysunków przy RSK i wizytator przy kuratorium lwowskim, ale był także cenionym malarzem. Natomiast Antoni Sołtykiewicz i Antoni Czarkowski, współpracując ze sobą, wspierali lokalne inicjatywy tworzenia klas paralelnych i zakładania filii przy galicyjskich gimnazjach ${ }^{29}$.

Delegatami Rady Szkolnej Krajowej na maturę byli jej członkowie, osoby do niej przydzielone, pracownicy wyższych uczelni, ewentualnie dyrektorzy innych szkół realnych. W pierwszych dziesięcioleciach XX w. najczęściej stosowane było to ostatnie rozwiązanie. Wśród delegatów, którzy byli pracownikami uczelni, znaleźli się m.in.: Władysław Zajączkowski, Kazimierz Żórawski, Placyd Dziwiński i Zdzisław Krygowski.

27 Informacje na podstawie analizy tabeli 3 oraz rubryk Kronika i Egzamin dojrzałości w sprawozdaniach galicyjskich szkół realnych za lata 1875/76-1917/18.

28 Informacje na podstawie analizy rubryki Egzaminy dojrzałości w szkołach realnych zamieszczonych w Sprawozdaniach RSK o stanie szkół średnich galicyjskich za lata 1872-1912 oraz rubryk Kronika i Egzamin dojrzałości w sprawozdaniach galicyjskich szkół realnych z lata 1875/76-1917/18.

29 PSB, t. VII/1, s. 88-89, 396-398; t. XLIII/2, z. 177, s. 199-201; T. Ochenduszko, Leksykon kadry kierowniczej..., s. 40-41, 135; idem, Antoni Sołtykiewicz - przedstawiciel nadzoru pedagogicznego w Galicji, „Nauczyciel i Szkoła. Miesięcznik PCEN w Rzeszowie” 2012, nr 1(25), s. 21-22. 
Zajączkowski był profesorem zwyczajnym na Politechnice Lwowskiej, kierownikiem Katedry Matematyki i rektorem Politechniki (1878/79 i 1885/86). W pracy naukowej zajmował się teorią równań różniczkowych, geometrią analityczną oraz matematycznymi metodami w fizyce.

Kazimierz Żórawski napisał szereg prac poświęconych zagadnieniom teorii równań różniczkowych, geometrii różniczkowej, teorii grup i mechaniki. Wśród stanowisk, które pełnił, wymienić warto funkcję rektora Uniwersytetu Jagiellońskiego (1917-1918) i dyrektora Departamentu Nauki i Szkolnictwa Wyższego w Ministerstwie Wyznań Religijnych i Oświecenia Publicznego (1920-1921).

Placyd Dziwiński to profesor matematyki i rektor Politechniki Lwowskiej (1893/94). Natomiast Zdzisław Krygowski, gdy nadzorował maturę jako delegat RSK, był profesorem zwyczajnym i szefem Katedry Matematyki na Politechnice Lwowskiej. W wolnej Polsce zainicjował prace kryptologiczne nad Enigmą, a słuchacze jego zajęć - Marian Rejewski, Henryk Zygalski i Jerzy Różycki złamali jej szyfr ${ }^{30}$.

Bywało, że delegatami zostawali zarządcy placówki, w której odbywał się egzamin. To rozwiązanie stosowano częściej podczas I wojny światowej. Mogło to wynikać z faktu, że część członków RSK przebywała poza jej siedzibą, która przeniesiona była ze Lwowa do Białej, a ta znajdowała się na zachodnim skraju Galicji ${ }^{31}$.

Warto przyjrzeć się owocom pracy osób odpowiedzialnych za przygotowanie i przebieg egzaminów dojrzałości. Rozproszone po różnych źródłach informacje dotyczące lat 1872/73-1913/14 zostały zebrane w tabeli $\mathrm{nr} 4$.

Jak wynika z tabeli, w latach 1872/73-1913/14 w 13 szkołach realnych do części ustnej podeszło 8370 abiturientów. Zdało ją 7051, co stanowiło 84,2\% egzaminowanych. W analizowanym okresie matura przez 41 lat odbywała się w I Szkole Realnej w Krakowie i w I Szkole Realnej we Lwowie, przez 38 lat w Szkole Realnej w Stanisławowie, a w innych zakładach przez kilkanaście lub kilka lat. Stąd też najwięcej abiturientów zdało egzamin dojrzałości właśnie w trzech wymienionych wyżej placówkach. W I Szkole Realnej we Lwowie świadectwo maturalne otrzymało 1801 byłych uczniów, w I Szkole Realnej w Krakowie - 1739, a w Szkole Realnej w Stanisławowie - 833. Warto zauważyć, że ponad 65\% wszystkich abiturientów zdało maturę w czterech szkołach realnych znajdujących się w miastach stołecznych, tj. we Lwowie i w Krakowie. Małe zainteresowanie młodzieży i rodziców szkołami realnymi, które występowało szczególnie na prowincji, budziło niepokój Rady Szkolnej Krajowej, która zezwalała na tworzenie mniej licznych klas w tych zakładach, które zorganizowane zostały później.

Liczba maturzystów w szkołach realnych zależała od kilku czynników: od zmieniających się przepisów, od sieci wszystkich szkół średnich w Galicji, od liczby miejsc w bursach i od warunków mieszkaniowych na prywatnych stancjach, od polityki oświatowej władz państwowych (austriackich) i krajowych (galicyjskich) oraz od sytuacji gospodarczej. Kryzys ekonomiczny z lat 1873-1879 spowodował mniejszy napływ młodzieży, co przełożyło się na spadek liczby maturzystów na przełomie lat

30 T. Ochenduszko Leksykon nauczycieli i wychowanków I Gimnazjum i Liceum w Rzeszowie, Rzeszów 2010, s. 184.

31 W. Pietryka, Miejsce rzeszowskich gimnazjów w strukturze organów państwowych i instytucji odpowiedzialnych za oświatę w latach 1914-1921, [w:] Rzeszów swoim bohaterom. Środowisko rzeszowskich gimnazjów wobec odzyskania niepodległości, praca zbiorowa: A. Miechowicz, K. Milcarek-Mróz, T. Ochenduszko, W. Pietryka, M. Świętoń, P. Wanat, Rzeszów 2020, s. 60. 
Tabela 4. Wynik matur ustnych w latach 1872/73-1913/14

\begin{tabular}{|l|c|c|c|c|}
\hline \multicolumn{1}{|c|}{ Nazwa szkoły } & $\begin{array}{c}\text { Liczba lat, } \\
\text { w których } \\
\text { odbywała się } \\
\text { matura }\end{array}$ & $\begin{array}{c}\text { Liczba zdają- } \\
\text { cych ogółem }\end{array}$ & Zdali & Nie zdali \\
\hline Sz.R. Jarosław (I) & 16 & 325 & 282 & 43 \\
\hline Sz.R. Jarosław (II) & 10 & 183 & 167 & 16 \\
\hline I Sz.R. Kraków & 41 & 2116 & 1739 & 377 \\
\hline II Sz.R. Kraków & 10 & 487 & 410 & 87 \\
\hline Sz.R. Krosno & 8 & 145 & 136 & 9 \\
\hline I Sz.R. Lwów & 41 & 2253 & 1801 & 452 \\
\hline II Sz.R. Lwów & 10 & 758 & 671 & 87 \\
\hline Sz.R. Stanisławów & 38 & 977 & 833 & 144 \\
\hline Sz.R. Stryj & 12 & 182 & 161 & 21 \\
\hline Sz.R. Śniatyn & 5 & 113 & 109 & 4 \\
\hline Sz.R. Tarnopol & 17 & 505 & 436 & 69 \\
\hline Sz.R. Tarnów & 10 & 279 & 260 & 19 \\
\hline Sz.R. Żywiec & 4 & 47 & 46 & 1 \\
\hline Razem & - & 8370 & 7051 & 1329 \\
\hline
\end{tabular}

Sz.R. - Szkoła Realna

Źródło: Opracowanie własne na podstawie informacji zawartych w sprawozdaniach Rady Szkolnej Krajowej o stanie szkół średnich galicyjskich za lata 1875-1912 oraz informacji w sprawozdaniach szkół realnych w Galicji za lata 1875/76-1913/14.

siedemdziesiątych i osiemdziesiątych XIX w. Z kolei rozwój sieci kolejowej i przemysłu budowlanego w latach dziewięćdziesiątych XIX w., a co za tym idzie, wzrost liczby miejsc pracy w przemyśle, rzemiośle i komunikacji, spowodował zwiększenie zainteresowania kształceniem przygotowującym fachowców, którzy będą potrzebni dla gospodarki ${ }^{32}$. Zaowocowało to po kilku latach wzrostem liczby osób zdających maturę. W roku szkolnym 1902/03 przekroczona została granica 200 osób, a w roku 1907/08 - granica 400. Najwięcej abiturientów (482) pozytywnie złożyło egzamin dojrzałości w roku 1910/1133.

Należy dodać, że w specyficznym okresie I wojny światowej funkcjonowało, z dłuższymi bądź krótszymi przerwami, dziesięć szkół realnych, które miały uprawnienia do przeprowadzania matur. Były to: Szkoła Realna w Jarosławiu, I Szkoła Realna w Krakowie, II Szkoła Realna w Krakowie, Szkoła Realna w Krośnie, I Szkoła Realna we Lwowie, II Szkoła Realna we Lwowie, Szkoła Realna w Stanisławowie, Szkoła Realna w Tarnobrzegu, Szkoła Realna w Tarnowie i Szkoła Realna w Żywcu.

32 Na związek liczby uczniów w szkołach realnych z sytuacją gospodarczą zwrócił uwagę w swoim artykule Jan Kobak - zob. idem, Historyczny pogląd na rozwój Wyższej Szkoły Realnej w Tarnopolu, [w:] Spr. Dyr. Gim. w Tarnopolu za lata szkolne 1896 i 1897, Tarnopol 1897, s. 8.

33 Informacje na podstawie analizy tabeli $\mathrm{nr} 4$. 
Organizowały one egzaminy dojrzałości w trybie normalnym i w trybie nadzwyczajnym - tzw. matury wojenne. Matury wojenne mogli zdawać w trakcie roku szkolnego nie tylko abiturienci, ale także powołani do wojska uczniowie klasy siódmej, a niekiedy nawet ci, którzy ukończyli klasę szóstą. W latach 1914/15-1917/18 egzamin dojrzałości w szkołach realnych złożyło co najmniej 745 osób, w tym 404, tj. 54,3\% w trybie normalnym, a 341, tj. 45,7\% - na mocy nadzwyczajnych przepisów. Dla tych ostatnich dyrektorzy i kierownicy zorganizowali co najmniej 214 terminów, co oznacza, że w jednym terminie zdawały średnio 2 osoby ${ }^{34}$.

Abiturientom prawie każdej ze szkół realnych, którzy składali egzaminy dojrzałości w latach 1872/73-1917/18 można by poświęcić oddzielne publikacje. Warto wspomnieć o kilku z nich. Maturę w I Szkole Realnej w Krakowie zdali: w 1889 r. Karol Rolle - prezydent Krakowa (1926-1931); w 1903 r. Władysław Kucharski - kierownik ministerstwa (1920), później minister do spraw byłej dzielnicy pruskiej (1921), a następnie minister przemysłu i handlu w rządzie Wincentego Witosa (1923); w 1908 r. Ferdynand Goetel - prozaik, dramatopisarz, publicysta, scenarzysta i działacz polityczny, uczestnik misji, która w 1943 r. badała groby oficerów polskich w Katyniu; w 1912 r. Józef Beck minister spraw zagranicznych II Rzeczypospolitej (1932-1939) ${ }^{35}$.

Egzamin dojrzałości w I Szkole Realnej we Lwowie zdali: w 1876 r. Tadeusz Fiedler - profesor Politechniki Lwowskiej, kierownik kilku katedr i dwukrotny rektor tej uczelni, zawodowy znawca szkolnictwa w RSK oraz jej delegat na egzaminy maturalne; w $1909 \mathrm{r}$. Adam Hoszowski - inżynier górniczy, dyrektor Sektora Kopalń Sanok (1945-1949), współzałożyciel pierwszego w Europie skansenu naftowego - Muzeum Przemysłu Naftowego im. Ignacego Łukasiewicza w Bóbrce; w 1910 r. Rudolf Indruch - architekt, autor projektu Cmentarza Orląt oraz Pomnika Obrońców Lwowa na Persenkówce ${ }^{36}$.

W II Szkole Realnej we Lwowie świadectwo dojrzałości otrzymali: w 1910 r. Wojciech Bucior - starosta powiatu sanockiego (1936-1939), zamordowany przez NKWD w 1940 r.; w 1915 r., na mocy przepisów wojennych, Włodzimierz Cieński naczelny kapelan Związku Walki Zbrojnej we Lwowie, żołnierz Polskich Sił Zbrojnych na Zachodzie; w 1916 r., według tej samej procedury, Henryk Bilor - założyciel i długoletni piłkarz klubu Czarni Lwów, ofiara zbrodni katyńskiej ${ }^{37}$.

Maturę w Gimnazjum w Stanisławowie w 1910 r. zdał Tadeusz Krynicki - obrońca Lwowa (1918-1919) i budowniczy fabryki w Mościcach ${ }^{38}$. Natomiast w 1878 r. świadectwo dojrzałości w Szkole Realnej w Jarosławiu otrzymał Roman Dzieślewski - nestor polskiej elektryki, pierwszy polski profesor elektrotechniki, rektor Politechniki Lwowskiej ${ }^{39}$.

W 1913 r. w Szkole Realnej w Krośnie maturę z wyróżnieniem zdało trzech uczniów. Byli to: Wiktor Kulczycki - dyrektor Zjednoczenia Przemysłu Naftowego w Krakowie, a później dyrektor Zarządu Przemysłu Naftowego w Krakowie; Stanisław Jugendfein - żołnierz Legionów Polskich, wojny polsko ukraińskiej, polsko-bolszewic-

34 T. Ochenduszko, Wojenne egzaminy..., s. 70-71.

35 Spr. Dyr. I Wyższej Szkoły Realnej w Krakowie za r. szk. 1889, s. 35; ...1903, s. 86; ...1908, s. 66; ...1912, s. 55; PSB, t. XVI, z. 68, s. 54-57, t. XXXI, z. 128, s. 167-168.

36 Spr. Dyr. I Wyższej Szkoły Realnej we Lwowie za r. szk. 1909, s. 50; ...1910, s. 72.

37 Spr. Dyr. II Wyższej Szkoły Realnej we Lwowie za r. szk. 1909/10, s. 90; ...1915/16, s. 38-39.

38 Spr. Dyr. Wyższej Szkoły Realnej w Stanisławowie za r. szk. 1909/10, s. 70.

39 PSB, t. VI, s. 167-168. 
kiej i kampanii wrześniowej, kierownik zakładów przetwórczych w Chorzowie, ofiara zbrodni sowieckiej w Bykowni, oraz Jarosław Indyszewski - działacz ukraińskich organizacji nacjonalistycznych, m.in. Ukraińskiej Organizacji Wojskowej ${ }^{40}$.

Matury w szkołach realnych zapewniły dopływ do zawodów technicznych sporej grupy inteligencji, która była niezbędna dla gospodarki najpierw galicyjskiej, a później II Rzeczypospolitej. Jednak wielu rodziców uważało, że ich dzieci będą miały większe szanse w dorosłym życiu po ukończeniu gimnazjów. Poważnym mankamentem szkół realnych było to, że ich absolwenci (od roku 1872/73) mogli wprawdzie kontynuować edukację na studiach technicznych, ale nie nabywali uprawnień, aby ubiegać się o przyjęcie na uniwersytety ${ }^{41}$. Problem ten postanowił rozwiązać Sejm Krajowy, uchwalając 15 października 1910 r. ustawę, która wydłużała naukę w szkołach realnych do ośmiu klas oraz wprowadzała takie zmiany programowe, aby wychowankowie mogli ubiegać się o przyjęcie do wszystkich szkół wyższych. Ustawa uzyskała 4 marca 1912 r. sankcję cesarską ${ }^{42}$, jednak z powodu wybuchu I wojny światowej nie zdążono wprowadzić jej w życie. Szkoły realne do końca swojego istnienia pozostały siedmioklasowymi ${ }^{43}$, a dyskusja nad ich reformą rozgorzała w pierwszych latach istnienia II Rzeczypospolitej. Jej przebieg i efekty warto przedstawić w oddzielnym artykule.

\section{Bibliografia}

\section{Źródła:}

Dziennik Urzędowy C.K. Rady Szkolnej Krajowej, r. XVI, nr 10 z 22 V 1912.

Dzienniki Ustaw i Rozporządzeń Krajowych dla Królestwa Galicji i Lodomerii wraz z Wielkim Księstwem Krakowskim za lata 1872, 1899.

Projekt zarysu organizacyjnego gimnazjów i szkół realnych, [w:] Ustawy i rozporządzenia obowiq̨zujące w galicyjskich szkołach średnich, oprac. H. Kopia, Lwów 1900. Sprawozdania galicyjskich szkół realnych za lata szkolne 1874/75-1917/18.

Sprawozdania C.K. Rady Szkolnej Krajowej o stanie szkół średnich galicyjskich za lata szkolne 1875-1911/12.

Sprawozdanie Dyrekcji Gimnazjum w Przemyślu za rok szkolny 1894, Przemyśl 1894. Sprawozdanie Dyrekcji Gimnazjum w Rzeszowie za rok szkolny 1861, Rzeszów 1861.

Szematyzmy Królestwa Galicji i Lodomerii z Wielkim Księstwem Krakowskim za lata 1853-1914.

\section{Opracowania:}

Błahut A., Ochenduszko T., Kasper Brzostowicz - pedagog, dyrektor szkoły, elektryk, „Maszyny Elektryczne - Zeszyty Problemowe”, nr 4/2016 (112), Katowice 2016. Bostel F., Reforma egzaminu dojrzałości, „Muzeum” 1908, r. XXIX, t. 1, z. 4.

40 Spr. Dyr. Wyższej Szkoły Realnej w Krośnie za r. szk. 1912/13, s. 57.

41 Chcąc podjąć studia na uniwersytecie musieli, po uzupełnieniu różnic programowych, zdać maturę w gimnazjum.

42 Dziennik Urzędowy C.K. Rady Szkolnej Krajowej, r. XVI, nr 10 z 22 V 1912, s. 209-211.

43 S. Możdżeń, Reformy szkoły średniej w Galicji w latach 1884-1914, Kielce 1989, s. 60. 
Historia Gimnazjum Przemyskiego, [w:] Sprawozdanie Dyrekcji Gimnazjum w Przemyślu za rok szkolny 1894, Przemyśl 1894.

Dutkowa R., Polityka szkolna $w$ Galicji między autonomiq a centralizmem (1861-1875), Kraków 1995.

Kobak J., Historyczny pogląd na rozwój Wyższej Szkoły Realnej w Tarnopolu, [w:] Sprawozdanie Dyrekcji Gimnazjum Tarnopolu za lata szkolne 1896 i 1897, Tarnopol 1897.

Możdżeń S., Reformy szkoły średniej w Galicji w latach 1884-1914, Kielce 1989.

Możdżeń S., Ustrój szkoły średniej w Galicji i próby jego modernizacji $w$ latach 1848-1888, Wrocław 1974.

Ochenduszko T., Antoni Sołtykiewicz - przedstawiciel nadzoru pedagogicznego w Galicji, „Nauczyciel i Szkoła. Miesięcznik PCEN w Rzeszowie” 2012, nr 1(25).

Ochenduszko T., Leksykon kadry kierowniczej gimnazjów galicyjskich $w$ okresie autonomii, Rzeszów 2015.

Ochenduszko T., Leksykon nauczycieli i wychowanków I Gimnazjum i Liceum w Rzeszowie, Rzeszów 2010.

Ochenduszko T., Rada Szkolna Krajowa we Lwowie, [w:] Sprawozdanie Dyrekcji I Liceum w Rzeszowie za rok szkolny 2013/14, Rzeszów 2014.

Ochenduszko T., Szkoły średnie w Stanisławowie w latach 1666-1918, „Prace Historyczno-Archiwalne", t. XXVIII, Rzeszów 2016.

Ochenduszko T., Wojenne egzaminy dojrzałości $w$ galicyjskich szkołach średnich $w$ latach 1914/15 - 1917/18, „Prace Historyczno-Archiwalne”, t. XXXII, Rzeszów 2020.

Ochenduszko T., Władysław Żłobicki - pedagog, urzędnik oświatowy, elektryk, „Maszyny Elektryczne - Zeszyty Problemowe", nr 4/2017 (116), Katowice 2017.

Ochenduszko T., Świętoń M., Filie galicyjskich szkół średnich w drugiej połowie XIX i na początku XX wieku, [w:] Sprawozdanie Dyrekcji I Gimnazjum w Rzeszowie za rok szkolny 2018/19, Rzeszów 2019.

Pietryka W., Miejsce rzeszowskich gimnazjów w strukturze organów państwowych i instytucji odpowiedzialnych za oświatę w latach 1914-1921, [w:] Rzeszów swoim bohaterom. Środowisko rzeszowskich gimnazjów wobec odzyskania niepodległości, praca zbiorowa: A. Miechowicz, K. Milcarek-Mróz, T. Ochenduszko, W. Pietryka, M. Świętoń, P. Wanat, Rzeszów 2020.

Polski Słownik Biograficzny, t. VI; t. VII/1; t. XVI, z. 68; t. XXXI, z. 128; t. XLIII/2, z. 177.

\section{Abstract}

\section{Matura Examinations in Galician Real Schools in 1872-1873 and 1917-1918}

Matura examinations in Galician real schools (realschule) were introduced in 1872 , after the schooling period had been extended from six to seven years.

The written matura examination consisted of an essay (then called an enclosed paper) in the language used during lectures, an essay in the state language, i.e. in German, a translation from German into the lecture language or vice versa, a translation from French into the lecture language, a mathematical task, and a task from descriptive geometry. During the autonomous period in Galicia, the lecture language in all 
real schools was Polish. Five hours each were allotted for an essay in Polish and tasks in descriptive geometry; four hours each for an essay in German and mathematical tasks; three hours each for translations from German into Polish (or vice versa) and for translations from French into Polish.

In the oral part, however, students had to take one language, geography and history (one subject back then), mathematics, natural history (combination of physics, chemistry, geography and biology), physics and chemistry. During the oral part, the committee was chaired by: the chairman, who was usually the national inspector of secondary schools or a delegate of the National School Council (NSC), the headmaster and all teachers who taught classes in the last grade, i.e. the seventh grade. The matura exam was a public examination, similar to the defense of a doctoral thesis. Therefore, it could be listened to by bystanders.

Out of 18 real schools that functioned during the described period, 15 met the conditions necessary to organize the matura exam. The principals of these establishments were responsible for observing the rules during the entire examination procedure, and if their positions were vacant, the responsibility fell on the vice principals, also known as managers. Between 1872-1873 and 1917-1918 there were 45 of these individuals.

The chairmen of the oral matura exam committees were national school inspectors or, alternatively, NSC delegates. They were elected from among the members of NSC, people assigned to the offices of this institution, employees of universities, usually technical ones, and directors of other real schools. During the period of interest, 33 officials served as chairmen. Jan Nepomucen Franke - chairman of the Section of Vocational, Real and Industrial Schools operating at the NSC - supervised the largest number of matura examinations (73).

In the years 1872-1873 and 1913-1914 the matura exam was passed by 7051 students. They constituted $84.2 \%$ of those who took the oral part. The largest number of students passed the exam in the First Realschule in Lviv (1801) and the First Realschule in Cracow (1739). The most famous graduate of the Cracow institution was Jozef Beck, who became Minister of Foreign Affairs of the Second Polish Republic from 1932 to 1939.

During the specific period of World War I, approximately 750 students passed their matura exams, of which nearly $46 \%$ passed under special regulations allowing students going to the front to take the war matura exam in a streamlined mode. Soon after Poland regained its independence, real schools were transformed into gymnasiums. Those that remained within the Polish borders after World War II continue to function to this day.

\section{Keywords:}

Real schools in Galicia, matura examinations in real schools, real school principals, school inspectors in Galicia, delegates of the National School Council. 